\title{
Evaluation of Sinuosity Index of Dhansiri (South) River Channel and Bank Erosion, Assam in GIS
}

\author{
Plabita Barman ${ }^{1}$, Dulal C.Goswami ${ }^{2}$ \\ Research Scholar, Department of Environmental Science, Gauhati University, Guwahati, Assam, India ${ }^{1}$ \\ Former Professor and Head, presently Guest Faculty, Department of Environmental Science, Gauhati University, \\ Guwahati, Assam, India ${ }^{2}$
}

\begin{abstract}
The Dhansiri River is a highly meandering river. Its Sinuosity Index has been evaluated using satellite imageries of 1999 and 2008 which varies from 1.22 to 4.91. The river acquires a meandering course as it flows through the alluvial plains of Assam and is responsible for frequent course change and shifting of banklines due to consistent bank erosion. The progressive gradual change of the meander bends has been observed by superimposing the river layers of 1999 and 2008 in GIS platform. The length of the river course in $2008(307.74 \mathrm{~km})$ became shorter by $6.20 \mathrm{~km}$ than that in $1999(313.94 \mathrm{~km})$. In the present study it has been found that the total area lost as a result of erosion is $13.13834 \mathrm{sq} \mathrm{km}$ and the total area gained as a result of sediment deposition along its bank is $15.15894 \mathrm{sq} \mathrm{km}$.
\end{abstract}

Keywords: Dhansiri River, Sinuosity Index, GIS, Landuse, Landcover, Erosion.

\section{INTRODUCTION}

A geometrically straight river is rare. All natural rivers, big or small, have an inherent tendency to deviate from a straight line and increase their sinuosity. Sinuosity is the ratio between channel length and valley length. The channel length is determined along the channel between two points on a river, and valley length is the straight line distance between the same two points [7]. The most significant morphological property of a sinuous river is the meandering process. A meander, in general, is a bend in a sinuous watercourse or river. A meander is formed when the moving water in a stream erodes the outer banks and widens its valley. The meandering process is dominated and governed by hydraulic, hydrologic and topographic characteristics of the river and its drainage area. In a meandering river, the length of the river keeps on increasing by eroding the outer bank of a bend [5].

A stream of any volume may assume a meandering course, alternately eroding sediments from the outside of a bend and depositing them on the inside. The result is a snaking pattern as the stream meanders back and forth across its down-valley axis. When a meander gets cut off from the main stream, an oxbow lake is formed. Over time meanders migrate downstream, sometimes in such a short time as to create civil engineering problems for local municipalities attempting to maintain stable roads and bridges.

The present study has been conducted to evaluate the sinuosity index of the Dhansiri (South) River using Remote sensing technology and Geographic information system. The sinuosity index of the river channel has been evaluated for two time period to observe the progressive gradual change of the mender bends that accounts for translational, lateral, rotational, extensional and other types of movements of the meander bends. An attempt has been made for quantitative assessment on the total amount of the bank area subjected to erosion during a period of time from 1999 to 2008.

The Sinuosity of the river ranges from 1.22 to 4.91 .

\section{STUDY AREA}

The Dhansiri(S) River is one of the major south bank tributaries of the Brahmaputra. It originates at an altitude of $1771 \mathrm{~m}$ at Laishang peak in Nagaland and outfalls into the Brahmaputra at Dhansirimukh.

The Dhansiri River traverses a distance of $356 \mathrm{~km}$ from its source which lies in the Laishang Peak on the south-west corner of Nagaland up to its confluence with the Brahmaputra at Dhansirimukh. For the first $40 \mathrm{~km}$ from its source, the river flows in a north westerly direction and thereafter it flows to north-east for about $76 \mathrm{~km}$ up to Dimapur. Beyong Dimapur, the direction of flow is generally northerly up to Golaghat, where the river takes an abrupt turn towards North West and ultimately joins the Brahmaputra. The part of the watershed that lies in Nagaland is covered by mountains and hill ranges, and partly by flat alluvial tract of the Brahmaputra Valley. The lower Dhansiri watershed comprises of unconsolidated sediments of Recent to sub- Recent age overlain by alluvial deposits of the Pleistocene age occur along the foothills.

The principal tributaries of the Dhansiri on the right bank are Diyung, Diphu and Gelabil and those on the left bank are Deopani, Nambor, Doigurung and Kaliyani.

For the present study almost the entire reach of the river flowing through the plains of Assam upto Dhansirimukh has been considered. 


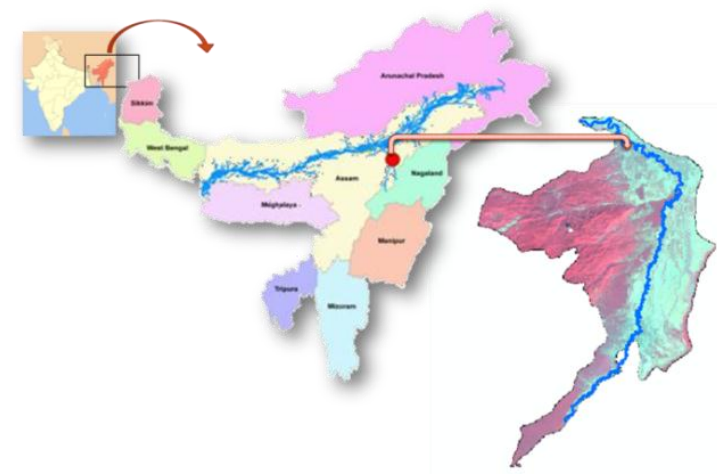

Fig. 1 Location Map of Dhansiri (South) River Channel, Assam

\section{MATERIAL AND METHODS}

The sinuosity index of the Dhansiri (South) River channel is evaluated from multi temporal Satellite images of Landsat ETM 1999 and IRS LISS III 2008 respectively. Landsat ETM 1999 satellite data are downloaded from GLCF website and IRS LISS III satellite data from Bhuvan website. The river channel of years 1999 and 2008 are digitized for the study area in ArcGIS 9.3 software. The sinuosity index is evaluated by taking continuous points along the entire length of the river channel of the two years 1999 and 2008 respectively. The digitized layers of the river channel for the respective years are then superimposed using overlay analysis. From the superimposed river channel of two time period data the nature of changes of the river channel are found out. The river channels of the two time period data are then united to estimate the area lost due to bank erosion and gained due to sediment deposition along different parts of the river.

\section{IV.RESULTS AND CONCLUSION}

The sinuosity index is calculated by taking continuous points along the entire length of the river channel using the formula CL/VL where CL is the channel length between two points on a river, and valley length is the straight line distance between the same two points. The sinuosity indexes thus derived for the two time period data are then plotted in a graph. It has been observed from the graphs that the sinuosity indexes increases as we move downstream the river channel. The sinuosity index is highest as the river flows through the fluvial sediments region of the study area. The sinuosity of the river channel varies from 1.22 to 4.91 . Thus the river Dhansiri may be termed as a highly meandering river based on the classification suggested by Leopold and Wolman (1957) [4]. The meandering nature of the river is responsible for frequent course change of the river as it flows through the plains of Assam. These results in frequent shifting of bankline of the river channel. Several types of meander bends along its bankline have been observed on superimposing the river layer of 2008 on the river layer of 1999. The frequency of the types of change in individual bend is analyzed by comparison with models of movements. For this purpose and to obtain a classification the primary elements of movement of Daniel (1971) [1] have been identified and grouped into double or triple combinations following Hooke (1977) [2].

The types of meander bends that has been noticed along the bankline of the river Dhansiri within the reach under study during the period 1999-2008 can be broadly grouped into two categories following Sarma et.al(2007) [3].

1. Neck cut-off at the meander loop leading to channel abandonment and straightening.

2. Progressive gradual change in meander bends as well as in straight parts of the channel (without neck cutoff).

Neck cut-off occurs when the meander loop becomes either nearly circular or when the two ends of the loop come very close; consequently, the river straightens the course at the neck of the meander bend resulting in abandonment of the meander loop and formation of oxbow lake (figure 2). Straightening of channel by neck cutoff along the studied reach is observed at 5 places during the period 1999-2008. Formation of new meander bends also observed at 3 places during this period. The length of the river channel as analyzed in GIS in 1999 was found to be $197.55 \mathrm{~km}$. The neck cut-offs had resulted in shortening of the channel course, and it is observed that the river course in $2008(307.74 \mathrm{~km})$ became shorter by $6.20 \mathrm{~km}$ than that in 1999 .

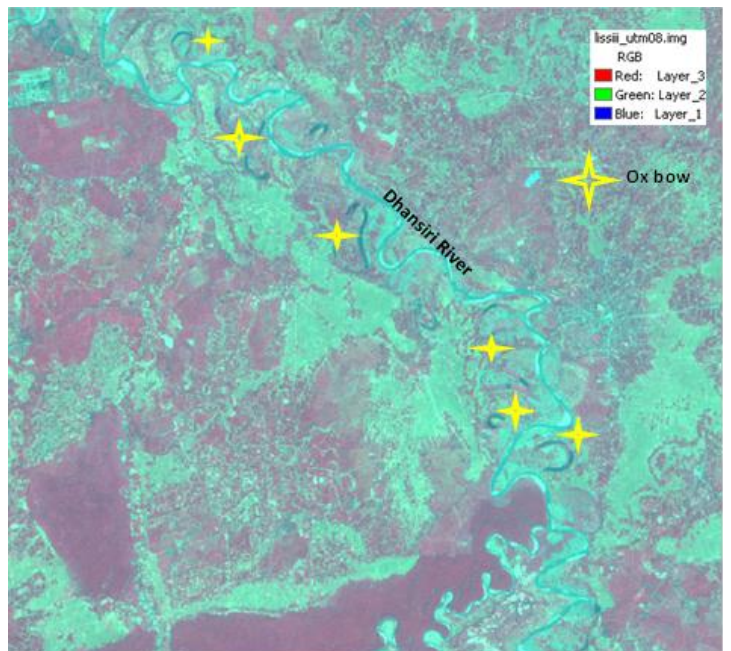

Fig. 2 A part of the LISS III 2008 Image showing the meandering pattern of the Dhansiri River and formation of ox bow lakes as a result of neck cut off

The other types of meander bends observed by superimposing the river layer of 2008 on the river layer of 1999 include rotation, translation, extension, lateral, narrowing/widening of the channel and complex. The frequency of occurrences of the different types of bends has also been evaluated. Rotation has been observed at 13 places along the river channel as it flows through the plains of Assam to its outfall at Dhansirimukh. Similarly translational type of meander bend has been observed at 36 places, extension at 22 places, lateral at 8 places, 
narrowing/widening at 3 places and complex type observed at 11 places along the river channel. Each type of movement can be in one of the two directions, i.e. upstream or downstream, increase or decrease or to the left or right.

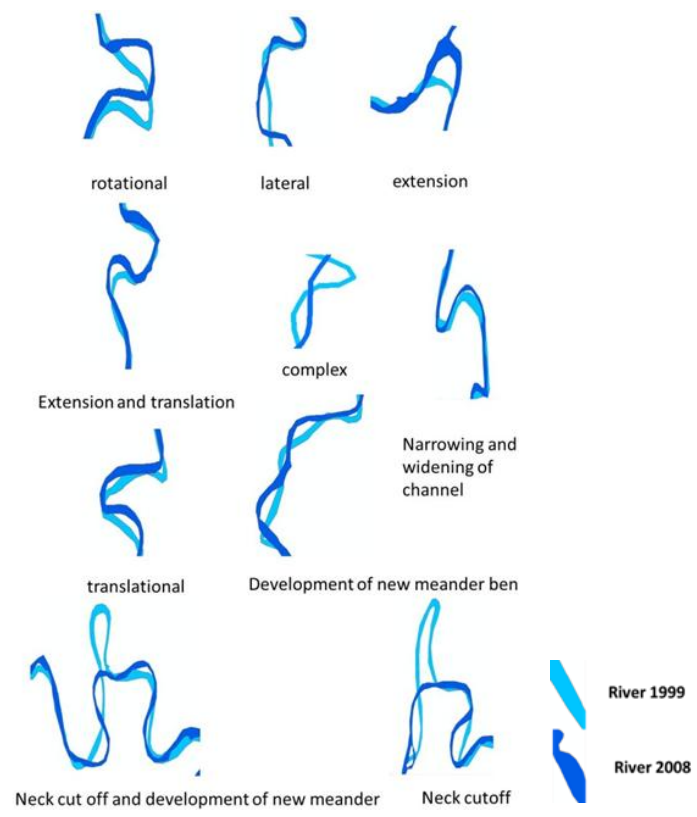

Fig. 3 Common types of movements of the meander bends in Dhansiri River Channel

Figure 3 represents common types of meander bends observed in Dhansiri River Channel. These types of meander bends occurring frequently causes shifting of the bankline of the Dhansiri River channel. This leads to heavy loss of land due to erosion by the river channel. In addition to that the river also carries soil lost as a result of deforestation in the hilly catchment of the river basin. These eroded soils are then transported by the river. As the river reaches the plains there is a sudden change of the river grade from a very steep slope to gentle slope as a result the transported sediments gets deposited in the river bed.

This process leads to meandering of the river channel and ultimately results in bank erosion. Hence in the present study an attempt has been made for estimating the bank area lost due to erosion and gained due to sediment deposition. It has been found that the total area lost as a result of erosion is $13.13834 \mathrm{sq} \mathrm{km}$ and the total area gained as a result of sediment deposition along its bank is $15.15894 \mathrm{sq} \mathrm{km}$. Figure 4 below represents a part of the Dhansiri river channel in LISS III Imagery of 2008 showing bankline shift and bank erosion as a result of course change of the river channel during the years 1999 to 2008 by superimposing the river layer of 1999 on the imagery.

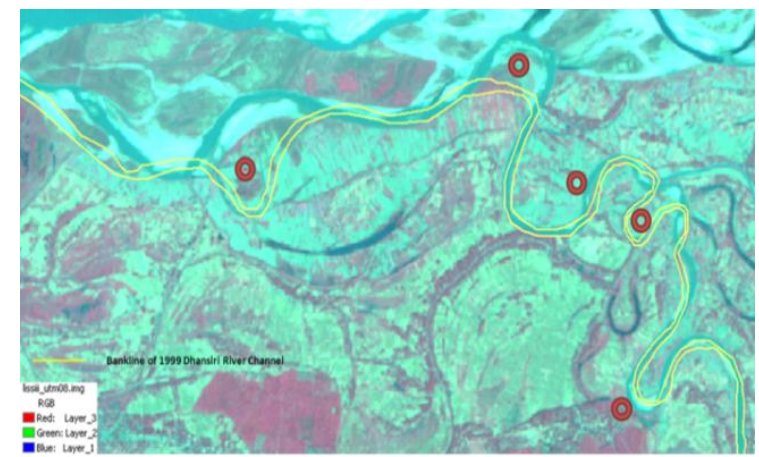

Fig. 4 A part of the LISS III 2008 Image Showing Bankline shift and Bank Erosion (O) during 1999-2008

The area loss under different landuse/landcover due to erosion during the past 9 years has been presented is table 1. The area developed as result of sediment deposition during the years 1999-2008 is presented in table 2 .

TABLE I

LANDUSE/LANDCOVER TYPES ERODED DURING 1999-2008

\begin{tabular}{|l|l|l|}
\hline S.No. & $\begin{array}{l}\text { Landuse/Landcover } \\
\text { types }\end{array}$ & Area in sq km \\
\hline 1 & Agricultural land & 6.618259 \\
\hline 2 & Forest & 0.823555 \\
\hline 3 & Settlement & 4.19931 \\
\hline 4 & $\begin{array}{l}\text { Vegetated bars/ } \\
\text { Fallow Sandbar }\end{array}$ & 1.973514 \\
\hline 5 & Tea plantation & 0.01596 \\
\hline \multicolumn{2}{|l|}{ Total area eroded } & 13.13834 \\
\hline
\end{tabular}

TABLE 2

LANDUSE/LANDCOVER TYPES DEVELOPED ON DEPOSITED SEDIMENTS DURING 1999-2008

\begin{tabular}{|l|l|l|}
\hline S.No. & $\begin{array}{l}\text { Landuse/Landcover } \\
\text { types }\end{array}$ & $\begin{array}{l}\text { Area in sq } \\
\mathbf{k m}\end{array}$ \\
\hline 1 & Agricultural land & 6.126456 \\
\hline 2 & Settlement & 3.794648 \\
\hline 3 & Sandbar & 2.548974 \\
\hline 4 & Tea plantation & 0.147339 \\
\hline 5 & Vegetated bar & 2.541519 \\
\hline \multicolumn{2}{|l|}{ Total area deposited } & 15.15894 \\
\hline
\end{tabular}

From the tables it is observed that among the landuse/landcover types agriculture and settlement are the areas that suffer highest erosion. The above observations reveal that within the last nine years more area got deposited along the bank of the Dhansiri River Channel. However the difference in areas that got eroded and deposited is not so significant. During the monsoon season the process of erosion gets aggravated as the water level recede the bank level. As the water level receded in the river channel, bank material gets saturated and lost support from the channel side. This results in shearing of blocks from the saturated bank due to its own weight. 
Bank erosion, shifting of the bankline of the river channel, loss of agricultural land, human settlements etc. are common phenomenon observed in the Dhansiri River basin. It is one of the most eroding river basins in India [6]. The highly meandering nature of channel as the river flows through alluvial sediments in the plains and excessive sediment discharge results in constant shifting of the bankline of the channel and has been continuing through ages.

\section{REFERENCES}

[1] J.F. Daniel, "Channel movement of meandering Indiana stream", U.S. Geological Survey, 1971, Professional Paper732-A.

[2] J.M. Hooke, Distribution and nature of changes in river channel pattern: The example of Devon. In: River Channel Changes (Ed: Gregory, K.J.). John Wiley and Sons Ltd. London, pp. 265-279, 1977.

[3] J.N. Sarma, D. Borah and U. Goswami, "Change of River Channel and Bank Erosion of the Burhi Dihing River (Assam), Assessed using Remote Sensing Data and GIS", Photonirvachak, Journal of the Indian Society of Remote Sensing,2007, Vol. 35, No. 1.

[4] L.B. Leopold, and M.G Wolman, "River channel Patterns- braided, meandering and straight", U.S. Geological Survey, 1957, Professional paper282-B.

[5] Mithun Deb, Dabojani Das, Misbah Uddin, "Evaluation of Meandering Characteristics Using RS \& GIS of Manu River", Journal of Water Resource and Protection, 2012, 4, 163-171.

[6] Nitashree Mili, Shukla Acharjee, "The Importance of Geomorphology in Understanding Natural Hazards with Special Reference to Hazards of The Dhansiri River Basin in The Golaghat District of Assam, India", Global Perspectives on Geography (GPG), 2014, Vol. 2.

[7] Vishwas S. Kale and Avijit Gupta, Channel Forms and Processes, Introduction to Geomorphology, Orient Longman Limited, pp. 128. 